\title{
Removal of azo-dye Acid Red B (ARB) by adsorption and catalytic combustion using magnetic $\mathrm{CuFe}_{2} \mathrm{O}_{4}$ powder
}

\author{
Rongcheng $\mathrm{Wu}$, Jiuhui $\mathrm{Qu}^{*}$, Hong He, Yunbo Yu \\ Research Center for Eco-Environmental Sciences, Chinese Academy of Sciences, Beijing 100085, China
}

Received 3 June 2003; received in revised form 4 September 2003; accepted 17 September 2003

\begin{abstract}
The effectiveness of magnetic $\mathrm{CuFe}_{2} \mathrm{O}_{4}$ powder as adsorbent/catalyst for the removal of azo-dye Acid Red B (ARB) from water by adsorption and subsequent catalytic combustion was studied. Magnetic $\mathrm{CuFe}_{2} \mathrm{O}_{4}$ powder showed excellent adsorption properties towards $\mathrm{ARB}$ at $\mathrm{pH}<5.5$, and it could be conveniently recovered by magnetic separation technology after adsorption. The combustion decomposition of ARB in the presence or absence of $\mathrm{CuFe}_{2} \mathrm{O}_{4}$ was studied by a system for thermal degradation studies (STDS) and in situ FTIR. The results indicated that different reactive pathways existed for the combustion under different conditions. In the presence of $\mathrm{CuFe}_{2} \mathrm{O}_{4}$, the temperature needed for oxidation reaction and for combustion was 150 and $300{ }^{\circ} \mathrm{C}$, respectively. The reaction products were observed to be $\mathrm{SO}_{2}$, $\mathrm{CO}_{2}$, $\mathrm{H}_{2} \mathrm{O}$, and nitrate. There was neither volatile organic compound (VOCs) emitted to atmosphere during reaction nor organic matter deposited on the surface of $\mathrm{CuFe}_{2} \mathrm{O}_{4}$ after the combustion. Comparatively, in the absence of $\mathrm{CuFe}_{2} \mathrm{O}_{4}$, the oxidation and combustion of ARB required a higher temperature $\left(300\right.$ and $500{ }^{\circ} \mathrm{C}$, respectively) and produced a lot of toxic organic compounds emitted to atmosphere besides $\mathrm{SO}_{2}$, $\mathrm{CO}_{2}$ and $\mathrm{H}_{2} \mathrm{O}$ during the reaction. In addition, sulfate was generated instead of nitrate. The experiments of adsorption-combustion cycles demonstrated that there was no evident change in adsorption properties and catalytic activity of magnetic $\mathrm{CuFe}_{2} \mathrm{O}_{4}$ powder after seven cycles. (c) 2003 Elsevier B.V. All rights reserved.
\end{abstract}

Keywords: Azo-dye removal; Adsorption; Catalytic combustion; $\mathrm{CuFe}_{2} \mathrm{O}_{4}$

\section{Introduction}

The complete mineralization of organic pollutants is the safest method to the environment, and some technologies, such as biotechnology and chemical oxidations, have been studied for or applied to the treatment of organic pollutants in water, atmosphere or soil [1,2]. But some of the contaminants such as aromatic halide or nitro aromatic substance and dyes have adequate resistance to oxidation by bio-degradation and conventional chemical oxidation. In view of the growing concern of environmental issues, alternative techniques must be found to meet the problem. Adsorption process and catalytic oxidation technologies are promising methods for the removal of various contaminants and have been studied for the removal of organic refractory pollutants from water $[3,4]$.

Adsorption process is one of the effective methods with the advantages of high treatment efficiency and no harmful

\footnotetext{
* Corresponding author. Tel.: +86-10-62849137; fax: +86-10-62849160.

E-mail address: rc_w@sohu.com (R. Wu).
}

by-product to treated water [5]. But adsorption process just transfers pollutants from one phase to another rather than eliminating them from the environment. When the adsorbents are used to adsorb toxic compounds or to decontaminate effluents, they become hazardous wastes that should be treated or disposed properly.

Catalytic oxidation has been extensively studied for the destruction of refractory and hazardous pollutants found in groundwater, surface water, and industrial wastewater. Currently, these oxidation technologies are usually used directly in raw water matrix for decomposing organic compounds $[6,7]$. However, these processes often have the disadvantages of the too large volumes of raw water to be treated in the oxidation system and, in some cases, incomplete mineralization of some contaminants and probably with some more toxic substances produced leading to the secondary pollution of the treated water or atmosphere [7]. In addition, it seems that the lower the concentration of contaminants is, the higher the cost for the mineralization of a defined amount of organic compounds tends to be.

So it appears attractive to combine adsorption with catalytic oxidation in a water treatment system, in which the 
contaminants are removed at first from a large volume of effluent by adsorption and pre-concentrated on adsorbent/catalyst material; and then separated from water; at last, mineralized by catalytic oxidation on the adsorbent/catalyst material, and the adsorbent/catalyst is regenerated at the same time. In such a process, the adsorption and oxidation operation is performed in different units, so the quality of treated water is only affected by the adsorption efficiency.

To achieve higher water treatment efficiency, the properties of adsorbent/catalyst are very important, including significant organic pollutant adsorption from solution and high catalytic activity for oxidation. At present, few of materials possess the property combining sufficient adsorption efficiency and excellent catalytic activity. There is a growing interest in inexpensive high surface area materials, especially metal oxides, and in their unique applications including adsorption and chemical catalysis [8,9]. It is known that the smaller the particles of adsorbent or catalyst are, the better its properties are, but the more difficult the recovery is. Powder iron oxides have relatively high surface area and catalytic activity. Many researchers have used the iron oxides to remove heavy metals and organic pollutants from tap or waste water $[10,11]$. Herrera et al. have studied the effectiveness of hematite fine particles as adsorbent/catalyst for adsorbing and catalytic combusting azo-dye Orange II and showed good results for the adsorption of hematite towards Orange II at about $\mathrm{pH}$ 3. But the solid/liquid separation was difficult and there were some harmful VOCs by-products formed during the combustion [12].

Magnetic separation is considered as a high speed and effective technique for separating magnetic particles. It has been used for many applications in biochemistry, microbiology, cell biology, analytical chemistry, mining ores, and environmental technology $[13,14]$. Thus, if the powder adsorbent/catalyst are magnetic, it could be recovered conveniently by magnetic separation technology.

It is known that copper ferrite is magnetic material. In this study, we evaluated the effectiveness of magnetic ferrite $\mathrm{CuFe}_{2} \mathrm{O}_{4}$ powder as an adsorbent/catalyst material for the removal of azo-dye Acid Red B (ARB), as a model organic pollutant, by adsorption-catalytic combustion. We focused on: firstly, the adsorption properties of magnetic $\mathrm{CuFe}_{2} \mathrm{O}_{4}$ powder towards ARB; secondly, the catalytic activity for adsorbed ARB combustion and the analyses of products formed during the reaction; and thirdly, the reusability of magnetic $\mathrm{CuFe}_{2} \mathrm{O}_{4}$ powder as an adsorbent/catalyst.

\section{Experimental}

\subsection{Materials}

$\mathrm{CuFe}_{2} \mathrm{O}_{4}$ was prepared by co-precipitation method. $0.01 \mathrm{~mol} \mathrm{Cu}\left(\mathrm{NO}_{3}\right)_{2} \cdot 3 \mathrm{H}_{2} \mathrm{O}$ and $0.02 \mathrm{~mol} \mathrm{Fe}\left(\mathrm{NO}_{3}\right)_{3} \cdot 9 \mathrm{H}_{2} \mathrm{O}$ was dissolved in $100 \mathrm{ml}$ of distilled water. Under vigorous magnetic-stirring, slowly raised the $\mathrm{pH}$ by adding $10 \%$
$\mathrm{NaOH}$ solution to around 10 and continued stirring for $30 \mathrm{~min}$, and then stopped stirring. The suspension was heated to $95-100^{\circ} \mathrm{C}$ for $2 \mathrm{~h}$. After cooling, the prepared magnetic adsorbent was repeatedly washed with distilled water. By magnetic separation, the solid was separated from water and dried at $50{ }^{\circ} \mathrm{C}$ for $5 \mathrm{~h}$ and at $110^{\circ} \mathrm{C}$ for $3 \mathrm{~h}$. The dry material was crushed and then calcinated at $300^{\circ} \mathrm{C}$ for $1 \mathrm{~h}$.

ARB was purchased from Beijing Chemicals Co. (Beijing, China) and used without further purification. Its structure is:

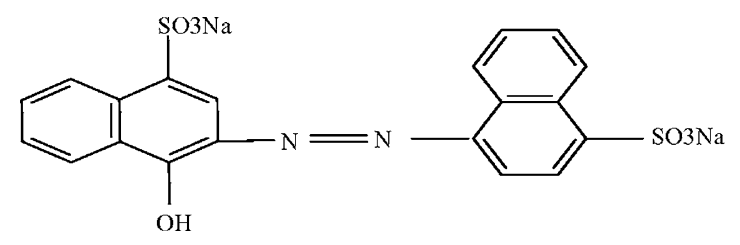

Deionized water was used throughout this study.

\subsection{Methods}

The crystalline structure of $\mathrm{CuFe}_{2} \mathrm{O}_{4}$ was determined using the X-ray powder diffraction method with a Rigaku III/B MAX diffractometer using Ni-filtered $\mathrm{Cu} \mathrm{K} \alpha$ radiation.

Specific saturation magnetization $\left(\sigma_{\mathrm{s}}\right)$ which is a measure of particle's magnetism was determined using a VSM model 155 magnetic meter.

Scanning electron microscopy/energy dispersive X-ray (SEM/EDAX) was carried out by means of Hitachi S-3500N Scanning Electron Microscope with an EDAX KEVEX Level 4.

BET surface area, pore diameter, and pore volume were determined by an ASAP2000 surface analyzer (Micromeritics Co., USA) and $\mathrm{N}_{2}$ as the adsorbate. Particle size of the adsorbent was determined by a Mastersizer 2000 (Malvern Co.).

Adsorption studies were carried out in glass vessels with agitation provided by a shaker. The temperature was controlled at $25^{\circ} \mathrm{C}$ by air bath. The $\mathrm{pH}$ was adjusted by addition of $\mathrm{HCl}$ or $\mathrm{NaOH}$. The suspension containing $0.100 \mathrm{~g} \mathrm{CuFe}_{2} \mathrm{O}_{4}$ adsorbent and varying amount of ARB was shaken on an orbit shaker at $140 \mathrm{rpm}$. Samples were taken at different time intervals. The concentration of ARB was determined by spectrophotometer (U-3010, Hitachi Co. ) at $516 \mathrm{~nm}$ or by TOC analyzer (Phoenix 8000 , Tekmar Dohrmann Co., USA) after $0.45 \mu \mathrm{m}$ membrane filtration.

For the adsorption rate and the effect of $\mathrm{pH}$ on adsorption experiments, $50 \mathrm{ml}$ ARB solution $(100 \mathrm{mg} / \mathrm{l})$ was used. Adsorption isotherms were conducted using the completely mixed batch reactor bottle-point method, and the solution $\mathrm{pH}$ was at 4.8.

The powder $\mathrm{CuFe}_{2} \mathrm{O}_{4}$ adsorbent was recovered by magnetic separation method with a permanent magnet of $40 \mathrm{~mm}$ diameter and $10 \mathrm{~mm}$ thickness, made with $\mathrm{Nd}-\mathrm{Fe}-\mathrm{B}$ (2300 G).

Thermal degradation tests were carried out with the following processes: After adsorption and magnetic separa- 
tion, the collected powder $\mathrm{CuFe}_{2} \mathrm{O}_{4}$ adsorbent containing adsorbed ARB was dried at $50^{\circ} \mathrm{C}$, and then placed into a quartz reactor. The air was let in at a flow of $30 \mathrm{ml} / \mathrm{min}$, and the quartz reactor temperature raised at $30{ }^{\circ} \mathrm{C} / \mathrm{min}$ and kept for $10 \mathrm{~min}$ at each specified temperature. The outlet gas with reaction products was first swept into a collector kept at $40^{\circ} \mathrm{C}$ for collecting reaction products which can be condensed below $40^{\circ} \mathrm{C}$. And then, from the collector, the gas was subsequently transferred into a high resolution mass spectrometer through a pipeline kept at $100^{\circ} \mathrm{C}$ for the analysis of low boiling point products. The MS was setup by scan mode at lowmass $=45$ and highmass $=350$.

The reaction products collected at $40^{\circ} \mathrm{C}$ were dissolved in $\mathrm{CH}_{2} \mathrm{Cl}_{2}$ and analyzed by a GC-MS instrument (GC: HP6890; MS: HP5973) equipped with a HP-5MS column $(60 \mathrm{~m} \times 0.32 \mathrm{~mm}, 0.25 \mu \mathrm{m}$ film thickness $)$. The oven temperature was held at $40^{\circ} \mathrm{C}$ for $2 \mathrm{~min}$ and then increased at a rate of $10^{\circ} \mathrm{C} / \mathrm{min}$ up to $280^{\circ} \mathrm{C}$ and held for $5 \mathrm{~min}$. By this system, all the VOCs formed during the catalytic combustion were determined qualitatively once the reaction started.

Diffuse reflectance (DRIFT) spectra of the azo-dye ARB and adsorbed ARB on $\mathrm{CuFe}_{2} \mathrm{O}_{4}$ were determined by a Nicolet 670 FTIR spectrophotometer equipped with a controlled-temperature and environment diffuse reflectance in situ chamber and a liquid nitrogen-cooled $\mathrm{HgCdTe}$ detector.

After catalytic combustion, the regenerated $\mathrm{CuFe}_{2} \mathrm{O}_{4}$ was recovered and was followed by washing with $10 \mathrm{ml} \mathrm{NaOH}$ solution of $\mathrm{pH} 8-9$ for further tests.

\section{Results and discussion}

\subsection{Characteristics of $\mathrm{CuFe}_{2} \mathrm{O}_{4}$}

The XRD analysis indicated the spinel structure of $\mathrm{CuFe}_{2} \mathrm{O}_{4}$, and surface morphology analysis by SEM showed the agglomeration of many microfine particles with diameter of about $100 \mathrm{~nm}$, which led to a rough surface and the presence of pores structure. The main characteristics of prepared $\mathrm{CuFe}_{2} \mathrm{O}_{4}$ are given in Table 1. It can be seen that $\mathrm{CuFe}_{2} \mathrm{O}_{4}$ powder has a surface area of $88.6 \mathrm{~m}^{2} / \mathrm{g}$, a mesopore structure with average pore diameter $70.2 \AA$ and a fine particle size of $11.7 \mu \mathrm{m}$. All these characteristics are in favor of adsorption. The specific saturation magnetization $\sigma_{\mathrm{s}}$ is $22.8 \mathrm{emu} / \mathrm{g}$. And in a batch experiment, $0.5 \mathrm{~g}$ of the magnetic powder $\mathrm{CuFe}_{2} \mathrm{O}_{4}$ adsorbent in $100 \mathrm{ml} \mathrm{H}_{2} \mathrm{O}$ was used for recovery test and a recovery ratio of above $98 \%$ was achieved with a permanent magnet $(2300 \mathrm{G})$. A

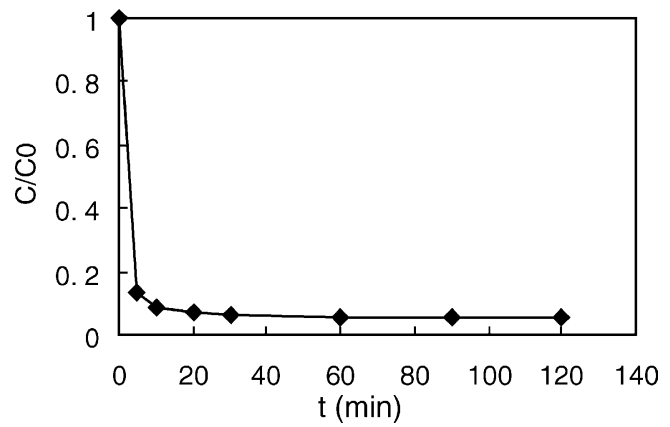

Fig. 1. Adsorption rate of $\mathrm{ARB}$ on $\mathrm{CuFe}_{2} \mathrm{O}_{4}$. $(50 \mathrm{ml} \mathrm{ARB}$ solution, initial concentration $100 \mathrm{mg} / \mathrm{l}, \mathrm{pH} 4.8 ; 0.100 \mathrm{~g} \mathrm{CuFe}_{2} \mathrm{O}_{4}$.)

higher recovery ratio could be attained if the magnetic field strength of permanent magnet is higher and much more of the magnetic adsorbent $\mathrm{CuFe}_{2} \mathrm{O}_{4}$ is used. Therefore, the magnetic adsorbent $\mathrm{CuFe}_{2} \mathrm{O}_{4}$ powder can be recovered efficiently by magnetic separation technology after adsorption or regeneration.

\subsection{Adsorption of $A R B$ onto $\mathrm{CuFe}_{2} \mathrm{O}_{4}$}

\subsubsection{Adsorption rate}

The effect of contact time on the removal of ARB by $\mathrm{CuFe}_{2} \mathrm{O}_{4}$ is illustrated in Fig. 1. As expected, the adsorption rate was very fast, and the equilibrium adsorption was almost achieved within $30 \mathrm{~min}$. This may be due to the fine particles of $\mathrm{CuFe}_{2} \mathrm{O}_{4}$ powder of average size $11.7 \mu \mathrm{m}$ and of mesopore structure as presented in Table 1. The smaller particle size was favorable for both the diffusion of dye molecules onto the active site of adsorbent and the complexation between the dye molecules and adsorbent. As a result, a higher adsorption efficiency was realized in a shorter adsorbing time.

\subsubsection{Effect of $p H$ on $A R B$ removal}

The effect of solution $\mathrm{pH}$ on adsorption varies significantly with different adsorbent or adsorbate. Fig. 2 shows the removal of ARB by $\mathrm{CuFe}_{2} \mathrm{O}_{4}$ at various $\mathrm{pH} .50 \mathrm{ml}$ ARB solution at the initial dye concentration of $100 \mathrm{mg} / \mathrm{l}$ was used. It indicates that the removal of ARB was strongly dependent on $\mathrm{pH}$. Acidic condition was favorable, especially at $\mathrm{pH}<5.5$. In this condition, the removal of ARB above 95\% was achieved. So adsorption of ARB by $\mathrm{CuFe}_{2} \mathrm{O}_{4}$ should be performed at $\mathrm{pH}<5.5$.

\subsubsection{Adsorption isotherm}

Adsorption capacity at different aqueous equilibrium concentration can be illustrated by the adsorption isotherm.

Table 1

Characteristics of magnetic $\mathrm{CuFe}_{2} \mathrm{O}_{4}$ powder

\begin{tabular}{|c|c|c|c|c|}
\hline Particle size $(\mu \mathrm{m})$ & $\begin{array}{l}\text { Specific saturation } \\
\text { magnetization }(\mathrm{emu} / \mathrm{g})\end{array}$ & $\begin{array}{l}\text { Surface area } \\
\left(\mathrm{m}^{2} / \mathrm{g}\right)\end{array}$ & $\begin{array}{l}\text { Average pore } \\
\text { diameter }(\AA)\end{array}$ & $\begin{array}{l}\text { Average pore } \\
\text { volume }\left(\mathrm{cm}^{3} / \mathrm{g}\right)\end{array}$ \\
\hline 11.7 & 22.8 & 88.6 & 70.2 & 0.14 \\
\hline
\end{tabular}




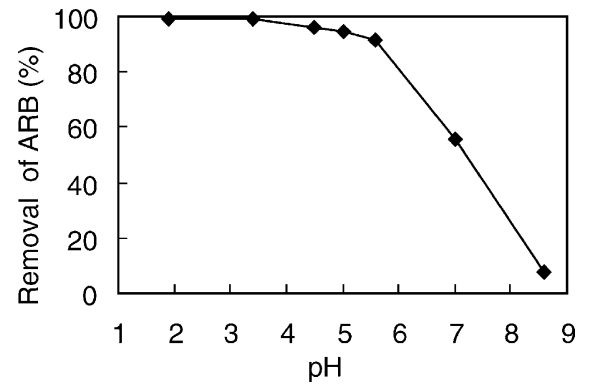

Fig. 2. Effect of $\mathrm{pH}$ on $\mathrm{ARB}$ removal. $(50 \mathrm{ml}$ ARB solution, initial concentration $100 \mathrm{mg} / \mathrm{l}, \mathrm{pH} 4.8 ; 0.100 \mathrm{~g} \mathrm{CuFe}_{2} \mathrm{O}_{4}$.)

Fig. 3 shows the adsorption isotherm of ARB on $\mathrm{CuFe}_{2} \mathrm{O}_{4}$ at $\mathrm{pH} 4.8$ and $20^{\circ} \mathrm{C}$. It is noted that the curve has a high slope in the initial portion and then levels off. This indicates that $\mathrm{CuFe}_{2} \mathrm{O}_{4}$ adsorbent has high adsorption density even at low equilibrium dye concentrations $c_{\mathrm{e}}$ and it also indicates that $\mathrm{CuFe}_{2} \mathrm{O}_{4}$ has a high affinity for ARB molecules, and this is favorable for removing dye from water to a lower concentration.

The adsorption data in Fig. 3 were fitted to Langmuir adsorption model very well with correlation coefficient $R^{2}=$ 0.998. The calculated maximum adsorption capacity $q_{\mathrm{m}}$ of $\mathrm{ARB}$ on $\mathrm{CuFe}_{2} \mathrm{O}_{4}$ at $\mathrm{pH} 4.8$ is $86.8 \mathrm{mg} / \mathrm{g}$.

Langmuir equation:

$q_{\mathrm{e}}=\frac{q_{\mathrm{m}} k c_{\mathrm{e}}}{1+k c_{\mathrm{e}}}$

where $q_{\mathrm{e}}$ (mg dye/g adsorbent) is the amount of dye adsorbed per gram of adsorbent at equilibrium; $q_{\mathrm{m}}(\mathrm{mg}$ dye $/ \mathrm{g}$ adsorbent) is the maximum adsorption capacity; $k(1 / \mathrm{mg})$ is the equilibrium adsorption constant; and $c_{\mathrm{e}}(\mathrm{mg} / \mathrm{l})$ is the equilibrium concentration of dye in solution.

The adsorption test indicated that $\mathrm{CuFe}_{2} \mathrm{O}_{4}$ was an excellent adsorbent for ARB adsorption at $\mathrm{pH}<5.5$.

\subsubsection{FTIR spectra for $A R B$ adsorption}

The FTIR spectra of ARB, adsorbed ARB on $\mathrm{CuFe}_{2} \mathrm{O}_{4}$ and initial $\mathrm{CuFe}_{2} \mathrm{O}_{4}$ is shown in Fig. 4. The peaks at 1603 and $1501 \mathrm{~cm}^{-1}$ are assigned to aromatic $\mathrm{C}=\mathrm{C}$ stretching vibration [15], while the weak peak at $1463 \mathrm{~cm}^{-1}$ is correspond to $-\mathrm{N}=\mathrm{N}-$ bond stretching vibration, and 1207 , $1436 \mathrm{~cm}^{-1}$ are assigned to $-\mathrm{C}-\mathrm{O}-$ bond stretching vibration

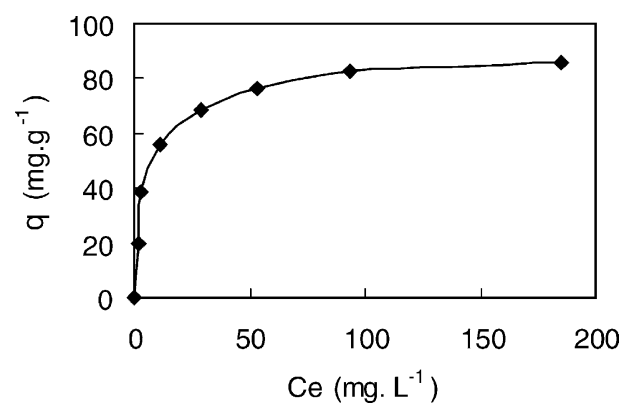

Fig. 3. Adsorption isotherm ARB on $\mathrm{CuFe}_{2} \mathrm{O}_{4}$ at $\mathrm{pH} 4.8$.

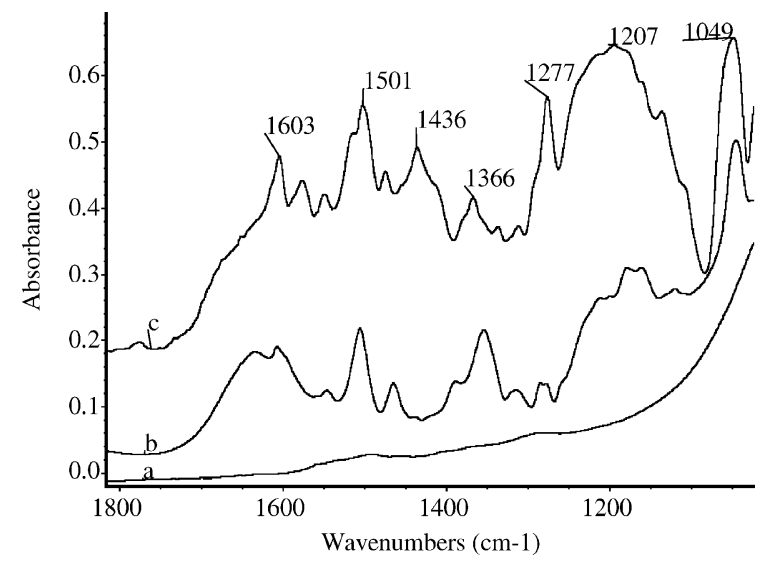

Fig. 4. FTIR spectra for ARB adsorption on $\mathrm{CuFe}_{2} \mathrm{O}_{4}$ : (a) $\mathrm{CuFe}_{2} \mathrm{O}_{4}$, (b) ARB adsorbed on $\mathrm{CuFe}_{2} \mathrm{O}_{4}$, and (c) ARB.

and $-\mathrm{OH}$ deformation, respectively. The $-\mathrm{SO}_{3}{ }^{-}$asymmetric vibrations is shown at $1277 \mathrm{~cm}^{-1}$ [16] and its symmetric stretching vibration overlaps with that of $-\mathrm{C}-\mathrm{O}-$ bond at about $1200 \mathrm{~cm}^{-1}$. It can be seen that peaks of adsorbed ARB on $\mathrm{CuFe}_{2} \mathrm{O}_{4}$ were similar to those of ARB except for the peaks at $1436 \mathrm{~cm}^{-1}(-\mathrm{OH})$ and $1277 \mathrm{~cm}^{-1}\left(-\mathrm{SO}_{3}{ }^{-}\right)$ that almost disappeared after adsorption, and the peak at $1200 \mathrm{~cm}^{-1}$ also changed obviously. This suggests the participation of both $-\mathrm{C}-\mathrm{OH}$ and $-\mathrm{SO}_{3}{ }^{-}$groups in bond formation with the adsorbent surface [17] and confirms the chemisorption of $\mathrm{ARB}$ on $\mathrm{CuFe}_{2} \mathrm{O}_{4}$.

\subsection{Catalytic combustion of $\mathrm{ARB}$ on $\mathrm{CuFe}_{2} \mathrm{O}_{4}$}

\subsubsection{Thermal degradation studies by system for thermal degradation studies (STDS)}

In the test, $50 \mathrm{mg} \mathrm{ARB}$ (by itself or adsorbed on $\mathrm{CuFe}_{2} \mathrm{O}_{4}$ ) was placed into the quartz reactor. The air was let in at a flow of $30 \mathrm{ml} / \mathrm{min}$, the quartz reactor temperature was raised to $30^{\circ} \mathrm{C} / \mathrm{min}$ and kept for $10 \mathrm{~min}$ at each specified temperature. The outlet gas with reaction products was first swept into a collector kept at $40^{\circ} \mathrm{C}$ for collecting high boiling point reaction products, and then the outlet gas was subsequently transferred into a high resolution mass spectrometer through a pipeline kept at $100^{\circ} \mathrm{C}$ for the analysis of low boiling point products. The MS was setup by scan mode at lowmass = 45 and highmass $=350$. The high boiling point reaction products collected at $40^{\circ} \mathrm{C}$ were dissolved in $\mathrm{CH}_{2} \mathrm{Cl}_{2}$ and analyzed by GC-MS. By this system, all the volatile organic compounds formed during the catalytic combustion were determined qualitatively once the reaction occurred.

Fig. 5 shows the ions abundance of reaction products at various temperature. It is indicated in Fig. 5 that the lowest temperature required for oxidation reaction in the presence or absence of $\mathrm{CuFe}_{2} \mathrm{O}_{4}$ was very different. In the presence of $\mathrm{CuFe}_{2} \mathrm{O}_{4}$, the oxidation reaction started at about $155^{\circ} \mathrm{C}$, which was $180^{\circ} \mathrm{C}$ lower than that of the reaction in the absence of $\mathrm{CuFe}_{2} \mathrm{O}_{4}$. By ion search, only two peaks at $\mathrm{m} / \mathrm{z} 48$ and 64 , corresponding to $\mathrm{SO}_{2}$, appeared in the mass 

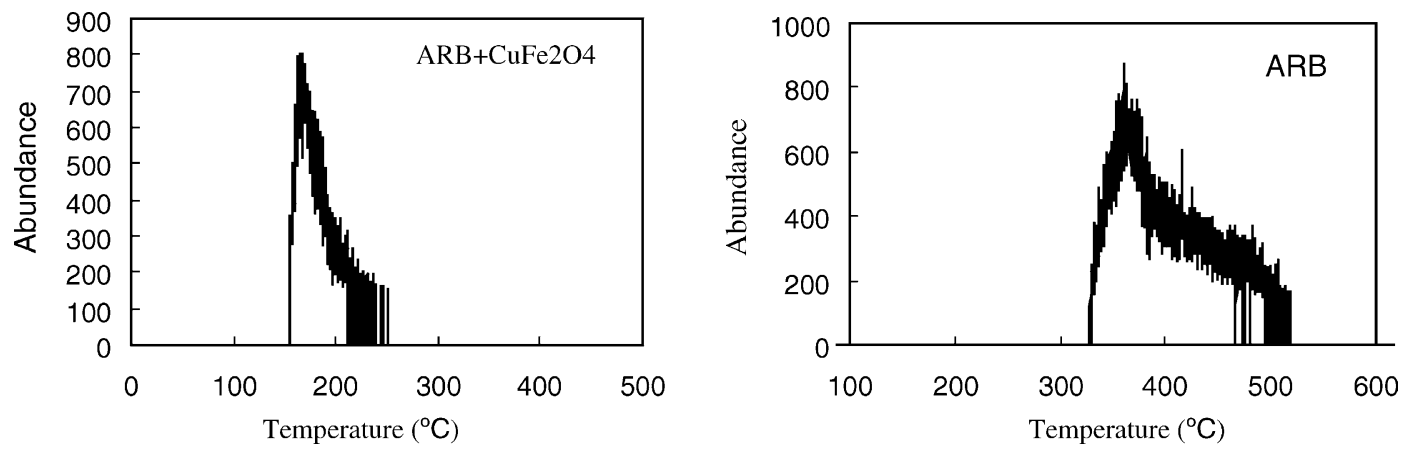

Fig. 5. Ions abundance for ARB combustion at various temperatures in the presence or absence of $\mathrm{CuFe}_{2} \mathrm{O}_{4}$.

spectra for $\mathrm{ARB} / \mathrm{CuFe}_{2} \mathrm{O}_{4}$ reaction. While in the absence of $\mathrm{CuFe}_{2} \mathrm{O}_{4}$, more peaks appeared in the mass spectra including the peaks at $\mathrm{m} / \mathrm{z} 45\left(\mathrm{CH}_{3} \mathrm{NO}\right.$ or $\left.\mathrm{HCO}-\mathrm{NH}_{2}\right), \mathrm{m} / z 45$ and $60\left(\mathrm{CH}_{3} \mathrm{NH}-\mathrm{NHCH}_{3}\right), \mathrm{m} / z 48$ and $64\left(\mathrm{SO}_{2}\right)$. This indicated that $\mathrm{CuFe}_{2} \mathrm{O}_{4}$ has excellent catalytic activity for ARB combustion, allowing a lower reaction temperature and no low boiling-point organic compound produced. Comparatively, a higher reaction temperature was needed in the absence of $\mathrm{CuFe}_{2} \mathrm{O}_{4}$ and much more by-products were generated.

The reaction products collected at $40^{\circ} \mathrm{C}$ for ARB combustion at different temperatures in the presence or absence of $\mathrm{CuFe}_{2} \mathrm{O}_{4}$ were also analyzed by GC-MS. The most important by-products detected are reported in Table 2 . It is noted in Table 2 that at all the temperatures used, no by-product was observed for the combustion of ARB in the presence of $\mathrm{CuFe}_{2} \mathrm{O}_{4}$. These results proved the total mineralization of ARB to $\mathrm{CO}_{2}$. In comparison, at the same temperature but in the absence of $\mathrm{CuFe}_{2} \mathrm{O}_{4}$, the thermal degradation of ARB led to a lot of organic by-products, such as: phenol, naphthalene, naphthol, aminonaphthalene, nitrile, phthalimide, $1,1^{\prime}$-dinaphthyl ether, and polycyclic aromatic hydrocarbons (PAHs). At higher temperatures, the number of by-products generally increased. This was in consistent with the results of oxidation of another azo-dye Orange II studied by Herrera et al. [12]. But in Herrera's study, there were also some harmful VOCs by-products, such as benzene, 2-naphthol, and nitrile, formed and emitted during the combustion in the presence of hematite at the temperature $250-600{ }^{\circ} \mathrm{C}$. Therefore, the catalytic activity of $\mathrm{CuFe}_{2} \mathrm{O}_{4}$ is higher than that of hematite.

The carbon balance during the combustion of adsorbed dye was also studied. In the test, a solution of $0.1 \mathrm{~mol} / \mathrm{l}$ $\mathrm{NaOH}$ was used to collect the gas produced during the reaction. After reaction, inorganic carbon (IC) and total organic carbon (TOC) of the solution were determined by IC/TOC analyzer. A blank experiment on the air collection was carried out at the same time to eliminate the influence of atmospheric $\mathrm{CO}_{2}$ on IC analysis. It was found that TOC of the solution was negligible. IC analysis indicated that nearly $100 \%$ of the initial C-content of the dye adsorbed on the $\mathrm{CuFe}_{2} \mathrm{O}_{4}$ was degraded to $\mathrm{CO}_{2}$. Only trace amounts of carbon were found on the $\mathrm{CuFe}_{2} \mathrm{O}_{4}$ surface after combustion and it might come from organic contaminants or adsorbed $\mathrm{CO}_{2}$.

The STDS experiment indicated the excellent catalytic activity of $\mathrm{CuFe}_{2} \mathrm{O}_{4}$ for adsorbed ARB combustion in air atmosphere. In the presence of $\mathrm{CuFe}_{2} \mathrm{O}_{4}$, a lower temperature needed for reaction was allowed, and there were no VOCs emitted to environment during the combustion. In comparison, without $\mathrm{CuFe}_{2} \mathrm{O}_{4}$, the temperature needed for oxidation reaction was higher, and there were lots of toxic VOCs emitted to environment during the combustion.

\subsubsection{In situ FTIR studies for $A R B$ and $A R B / C u F e 2 O 4$ combustion reaction}

As mentioned above, the combustion of ARB in the presence or absence of $\mathrm{CuFe}_{2} \mathrm{O}_{4}$ showed marked difference both in the temperature needed for reaction and the reaction products. In order to obtain insights into the reaction process, combustion of ARB in the presence or absence of $\mathrm{CuFe}_{2} \mathrm{O}_{4}$ was studied by means of in situ DRIFT spectroscopy. In the test, $10 \mathrm{mg}$ ARB (by itself diluted by $\mathrm{KBr}$ or adsorbed on $\mathrm{CuFe}_{2} \mathrm{O}_{4}$ ) were placed into the in situ reactor, and the air was let in at a flow of $30 \mathrm{ml} / \mathrm{min}$. The infrared spectra of the combustion at different temperatures are shown in Figs. 6 and 7 for $\mathrm{ARB}$ and $\mathrm{ARB} / \mathrm{CuFe}_{2} \mathrm{O}_{4}$, respectively.

In the absence of $\mathrm{CuFe}_{2} \mathrm{O}_{4}, \mathrm{ARB}$ was stable at the temperature below $300^{\circ} \mathrm{C}$ (Fig. 6). At $300^{\circ} \mathrm{C}$, the peaks

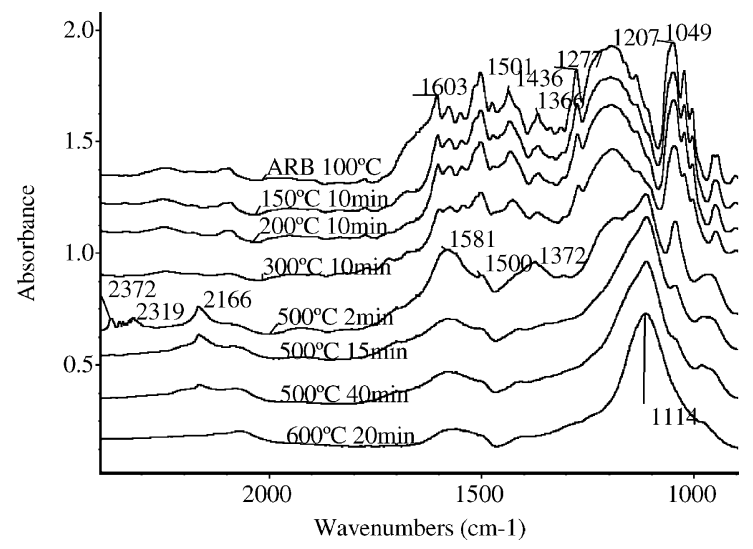

Fig. 6. FTIR spectra for ARB combustion in the absence of $\mathrm{CuFe}_{2} \mathrm{O}_{4}$ at different temperatures. 
Table 2

By-product identification during $\mathrm{ARB}$ combustion at different temperature in the presence or absence of $\mathrm{CuFe}_{2} \mathrm{O}_{4}$

\begin{tabular}{|c|c|c|c|c|c|c|}
\hline No. & Compound & $\mathrm{ARB}+\mathrm{CuFe}_{2} \mathrm{O}_{4}\left(300^{\circ} \mathrm{C}\right)$ & $\mathrm{ARB}\left(300^{\circ} \mathrm{C}\right)$ & $\mathrm{ARB}\left(400^{\circ} \mathrm{C}\right)$ & $\mathrm{ARB} \cdot\left(500^{\circ} \mathrm{C}\right)$ & $\mathrm{ARB}\left(500^{\circ} \mathrm{C}\right)$ \\
\hline 1 & & No & Yes & Yes & Yes & Yes \\
\hline 2 & & No & Yes & Yes & Yes & No \\
\hline 3 & & No & Yes & No & No & Yes \\
\hline 4 & & No & Yes & Yes & Yes & Yes \\
\hline 5 & & No & Yes & Yes & Yes & Yes \\
\hline 6 & & No & No & Yes & Yes & No \\
\hline 7 & & No & No & Yes & Yes & Yes \\
\hline 8 & & No & No & No & Yes & Yes \\
\hline 9 & & No & No & No & No & Yes \\
\hline 10 & & No & No & No & No & Yes \\
\hline 11 & & No & No & No & No & Yes \\
\hline 12 & & No & No & No & No & Yes \\
\hline 13 & & No & No & No & No & Yes \\
\hline 14 & & No & No & No & No & Yes \\
\hline
\end{tabular}




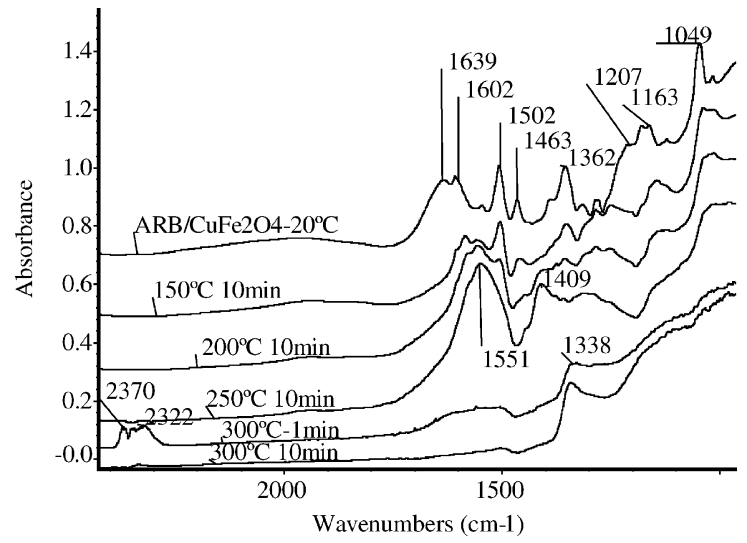

Fig. 7. FTIR spectra for $\mathrm{ARB} / \mathrm{CuFe}_{2} \mathrm{O}_{4}$ combustion at different temperatures.

of $\mathrm{ARB}$ were similar to those of $\mathrm{ARB}$ at the temperature below $300{ }^{\circ} \mathrm{C}$ except that the peak at $1277 \mathrm{~cm}^{-1}\left(-\mathrm{SO}_{3}{ }^{-}\right)$ decreased and the weak peak at $1463 \mathrm{~cm}^{-1}(-\mathrm{N}=\mathrm{N}-)$ almost disappeared after $10 \mathrm{~min}$. This suggests the reaction of $\mathrm{N}=\mathrm{N}-$ and $-\mathrm{SO}_{3}{ }^{-}$at $300^{\circ} \mathrm{C}$, and this initial reaction temperature was in consistent with the results by STDS studies described previously. At $500^{\circ} \mathrm{C}$, the spectra changed drastically after heating $2 \mathrm{~min}$. The asymmetric vibration $\mathrm{O}-\mathrm{S}\left(\mathrm{O}_{2}\right)$ at $1277 \mathrm{~cm}^{-1}$ disappeared, while the stretching vibration $\mathrm{C}=\mathrm{C}$ and $\mathrm{C}-\mathrm{O}$ at 1500 and $1207 \mathrm{~cm}^{-1}$ also decreased, respectively. Simultaneously, some new peaks appeared at $1114 \mathrm{~cm}^{-1}\left(\mathrm{SO}_{4}{ }^{2-}\right), 1372 \mathrm{~cm}^{-1}\left(-\mathrm{NO}_{2}\right)$, $1581 \mathrm{~cm}^{-1}(-\mathrm{NO}), 2166 \mathrm{~cm}^{-1}(-\mathrm{C} \equiv \mathrm{N}$ or $\mathrm{N}=\mathrm{C}=\mathrm{O}) . \mathrm{CO}_{2}$ peaks between 2319 and $2372 \mathrm{~cm}^{-1}$ also appeared. All these indicated the fast oxidation of ARB with the production of $\mathrm{CO}_{2}$, sulfate and some organic by-products. After $40 \mathrm{~min}$, the peaks at $1372 \mathrm{~cm}^{-1}\left(-\mathrm{NO}_{2}\right)$ and $1207 \mathrm{~cm}^{-1}(\mathrm{C}-\mathrm{O})$ disappeared, the peak at $2166 \mathrm{~cm}^{-1}(-\mathrm{C} \equiv \mathrm{N}$ or $-\mathrm{N}=\mathrm{C}=\mathrm{O})$ and the peaks between 1500 and $1600 \mathrm{~cm}^{-1}(\mathrm{C}=\mathrm{C})$ decreased, but not disappeared completely. Even at $600{ }^{\circ} \mathrm{C}$, and reacted for $20 \mathrm{~min}$, the peaks between 1500 and $1600 \mathrm{~cm}^{-1}$ still remained. These results indicated that, at $500^{\circ} \mathrm{C}$, all groups of ARB molecules were oxidized, but the oxidation was not complete even at the temperature as high as $600^{\circ} \mathrm{C}$. The residues included some organic compounds and sulfate, but no visible amount of nitrate was generated.
Fig. 7 shows the combustion reaction of adsorbed ARB in the presence of $\mathrm{CuFe}_{2} \mathrm{O}_{4}$. It can be seen that at $150^{\circ} \mathrm{C}$, the spectra already changed evidently: the peaks between 1100 and $1250 \mathrm{~cm}^{-1}\left(-\mathrm{SO}_{3}{ }^{-}\right.$and $\left.-\mathrm{C}-\mathrm{O}\right)$ decreased, which means the reaction of $\mathrm{ARB}$ on $\mathrm{CuFe}_{2} \mathrm{O}_{4}$ at $150^{\circ} \mathrm{C}$. This is also consistent with the results by STDS studies. At $200{ }^{\circ} \mathrm{C}$, the changes in spectra were more drastic: The peaks between 1100 and $1250 \mathrm{~cm}^{-1}\left(-\mathrm{SO}_{3}{ }^{-}\right.$and $\left.-\mathrm{C}-\mathrm{O}\right)$ and $1463 \mathrm{~cm}^{-1}(-\mathrm{N}=\mathrm{N}-)$ were very weak, while a new peak at $1551 \mathrm{~cm}^{-1}\left(-\mathrm{NO}_{2}\right)$ appeared. This indicated that the oxidation of $-\mathrm{N}=\mathrm{N}-$ to nitro-compounds and the further oxidation of $-\mathrm{SO}_{3}{ }^{-}$and $-\mathrm{C}-\mathrm{OH}$ had taken place. At $250{ }^{\circ} \mathrm{C}$, the peaks between 1100 and $1250 \mathrm{~cm}^{-1}\left(-\mathrm{SO}_{3}{ }^{-}\right.$ and $-\mathrm{C}-\mathrm{O})$ and $1463 \mathrm{~cm}^{-1}(-\mathrm{N}=\mathrm{N}-)$ almost disappeared and the peak at $1551 \mathrm{~cm}^{-1}\left(-\mathrm{NO}_{2}\right)$ increased rapidly. At $300{ }^{\circ} \mathrm{C}$, the peaks between 1500 and $1650 \mathrm{~cm}^{-1}(\mathrm{C}=\mathrm{C}$, and $-\mathrm{NO}_{2}$ ) decreased drastically, and the peaks at $1338 \mathrm{~cm}^{-1}$ $\left(\mathrm{NO}_{3}{ }^{-}\right), 2321-2370 \mathrm{~cm}^{-1}\left(\mathrm{CO}_{2}\right)$ appeared rapidly at the same time, which confirmed that the fast oxidation of aryl and $-\mathrm{NO}_{2}$ to $\mathrm{CO}_{2}$ and nitrate had taken place, respectively. After 10 min reaction, only the peak at $1338 \mathrm{~cm}^{-1}\left(\mathrm{NO}_{3}{ }^{-}\right)$ left was obvious, while the peak at $1114 \mathrm{~cm}^{-1}\left(\mathrm{SO}_{4}{ }^{2-}\right)$ was very weak. It is indicated in Fig. 7 that the adsorbed ARB was completely oxidized by catalytic combustion in the presence of $\mathrm{CuFe}_{2} \mathrm{O}_{4}$ and no organic compound residue left after combustion. Nitrate was the main residue and sulfate was very little. This was different with that of the combustion of ARB in the absence of $\mathrm{CuFe}_{2} \mathrm{O}_{4}$ with the residues of some organic compounds and sulfate instead of nitrate. SEM/EDAX analysis also demonstrated much more $\mathrm{N}$ element on the surface of $\mathrm{CuFe}_{2} \mathrm{O}_{4}$ than $\mathrm{S}$ by mole ratio of $\mathrm{N} / \mathrm{S}=8.6 / 1$ after combustion. To summarise, the main reaction process has been described in Table 3 .

\subsection{Reusability of $\mathrm{CuFe}_{2} \mathrm{O}_{4}$}

Seven adsorption-combustion cycles were carried out to evaluate the reusability of magnetic $\mathrm{CuFe}_{2} \mathrm{O}_{4}$ powder as adsorbent/catalyst for the removal of ARB. Fig. 8 shows the removal of ARB during the seven cycles, from $50 \mathrm{ml}$ solution of initial concentration $100 \mathrm{mg} / \mathrm{l}$ at $\mathrm{pH} 4.8 . \mathrm{CuFe}_{2} \mathrm{O}_{4}$ was washed after each combustion using a $\mathrm{NaOH}$ solution of $\mathrm{pH} \mathrm{8-9}$ for the removal of nitrate and sulfate formed

Table 3

The main reaction processes of $\mathrm{ARB}$ and $\mathrm{ARB} / \mathrm{CuFe}_{2} \mathrm{O}_{4}$ during combustion at different temperature

\begin{tabular}{|c|c|c|c|c|}
\hline \multirow[t]{2}{*}{ Temperature $\left({ }^{\circ} \mathrm{C}\right)$} & \multicolumn{2}{|l|}{ Main groups reacted } & \multicolumn{2}{|l|}{ Main products } \\
\hline & $\mathrm{ARB}$ & $\mathrm{ARB} / \mathrm{CuFe}_{2} \mathrm{O}_{4}$ & $\mathrm{ARB}$ & $\mathrm{ARB} / \mathrm{CuFe}_{2} \mathrm{O}_{4}$ \\
\hline 150 & - & $-\mathrm{SO}_{3}^{-},-\mathrm{OH}$ & - & $\mathrm{SO}_{2}$ \\
\hline $200-250$ & - & $-\mathrm{SO}_{3}{ }^{-},-\mathrm{OH},-\mathrm{N}=\mathrm{N}-$ & - & $\mathrm{SO}_{2}, \mathrm{R}-\mathrm{NO}_{2}$ \\
\hline 300 & $-\mathrm{SO}_{3}{ }^{-},-\mathrm{N}=\mathrm{N}-$ & $-\mathrm{C}=\mathrm{C}-,-\mathrm{NO}_{2}$ & $\mathrm{SO}_{2}$ & $\mathrm{CO}_{2}, \mathrm{H}_{2} \mathrm{O}, \mathrm{NO}_{3}^{-}$ \\
\hline 500 & $\begin{array}{l}-\mathrm{SO}_{3}{ }^{-}, \text {aromatic ring }-\mathrm{C}=\mathrm{C}- \\
-\mathrm{OH},-\mathrm{N}=\mathrm{N}-\end{array}$ & - & $\mathrm{SO}_{2}, \mathrm{CO}_{2}, \mathrm{H}_{2} \mathrm{O}, \mathrm{SO}_{4}{ }^{2-}, \mathrm{R}-\mathrm{C} \equiv \mathrm{N}, \mathrm{R}-\mathrm{N}=\mathrm{C}=\mathrm{O}, \mathrm{R}-\mathrm{NO}$ & - \\
\hline 600 & $\begin{array}{l}-\mathrm{C}=\mathrm{C}-, \mathrm{R}-\mathrm{C} \equiv \mathrm{N}, \mathrm{R}-\mathrm{N}=\mathrm{C}=\mathrm{O} \\
\mathrm{R}-\mathrm{NO}\end{array}$ & - & $\mathrm{CO}_{2}, \mathrm{H}_{2} \mathrm{O}$ & - \\
\hline Residue & - & - & PAHs, sulfate & Nitrate \\
\hline
\end{tabular}




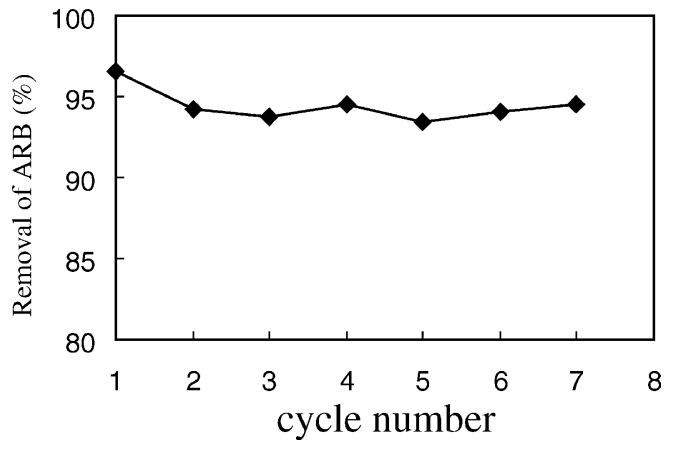

Fig. 8. Reusability of $\mathrm{CuFe}_{2} \mathrm{O}_{4}$ for the removal of $\mathrm{ARB}$ during seven cycles, for $50 \mathrm{ml}$ ARB solution of initial concentration $100 \mathrm{mg} / \mathrm{l}$ at $\mathrm{pH} 4.8$.

in the oxidation reaction. The results demonstrated that the removal of ARB by $\mathrm{CuFe}_{2} \mathrm{O}_{4}$ adsorption from water only decreased slightly after the first cycle, and then it reached a stable state in the following cycles. Analyses of combustion products and FTIR study for the reaction process in the seventh cycle did not show evident change as compared to that of the first cycle. These experiments demonstrated that $\mathrm{CuFe}_{2} \mathrm{O}_{4}$ as adsorbent/catalyst could be used repeatedly over many cycles.

\section{Conclusions}

1. Magnetic $\mathrm{CuFe}_{2} \mathrm{O}_{4}$ powder was proven to possess excellent adsorptive properties towards azo-dye ARB at $\mathrm{pH}<$ 5.5. And it can be conveniently recovered by magnetic separation technology after adsorption.

2. $\mathrm{CuFe}_{2} \mathrm{O}_{4}$ powder has high catalytic activity for the combustion of adsorbed ARB. The oxidative combustion reaction could be carried out at relatively low temperature, and no organic product emitted to atmosphere or deposited on the $\mathrm{CuFe}_{2} \mathrm{O}_{4}$ surface after combustion.

3. Magnetic $\mathrm{CuFe}_{2} \mathrm{O}_{4}$ powder is an excellent adsorbent/ catalyst for the removal of azo-dye ARB by adsorptioncatalytic combustion and can be used repeatedly.

\section{Acknowledgements}

This work was supported by the National Science Fund for Distinguished Young scholars (Grant 50225824).

\section{References}

[1] H.H.W. Lee, G. Chen, P.L. Yue, Water Sci. Technol. 44 (5) (2001) 75.

[2] G. Bertanza, C. Collivignarelli, R. Pedrazzani, Water Sci. Technol. 44 (5) (2001) 109.

[3] S.H. Lee, D.I. Song, Y.W. Jeon, Environ. Technol. 22 (2001) 247.

[4] C. Catrinescu, C. Teodosiu, M. Macoveanu, J. Miehe-Brendle, R.L. Dred, Water Res. 37 (2003) 1154

[5] S.J. Allen, Types of Adsorbent Materials-Use of Adsorbents for the Removal of Pollutants from Wastewaters, CRC, Boca Raton, FL, USA, 1996, p. 59.

[6] W.P. Kwan, B.M. Voelker, Environ. Sci. Technol. 37 (2003) 1150.

[7] L. Oliviero, J. Barbier Jr., D. Duprez, Appl. Catal. B 40 (2003) 163.

[8] E.A. Deliyanni, D.N. Bakoyannakis, A.I. Zouboulis, K.A. Matis, Chemosphere 50 (2003) 155.

[9] M. Baldi, V.S. Escribano, J.M.G. Amores, F. Milella, G. Busca, Appl. Catal. B 17 (1998) L175.

[10] B. Gu, J. Schmitt, Z. Chen, L. Liang, J.F. McCarthy, Environ. Sci. Technol. 28 (1994) 38

[11] S.G.J. Heijman, A.M. Paassen, W.G.J. Meer, R. Hopman, Water Sci. Technol. 40 (9) (1999) 183.

[12] F. Herrera, A. Lopez, G. Mascolo, P. Albers, J. Kiwi, Appl. Catal. B 29 (2001) 147.

[13] A.F.M. van Velsen, G. van der Vos, Water Sci. Technol. 24 (10) (1991) 195

[14] A.D. Ebner, J.A. Ritter, H.J. Ploehn, Sep. Sci. Technol. 34 (1999) 1277.

[15] R. Silverstein, T. Clayton, T. Morril, Spectrophotometric Identification of Organic Compounds, Wiley, New York, 1991, p. 106.

[16] G. Centi, Environmental Catalysis, Ital. Chem. Soc. Pub., Rome, 1995, p. 245.

[17] J. Bandara, J.A. Mielczarski, J. Kiwi, Langmuir 15 (1999) 7670. 